\title{
A Method for Collecting and Staining Vaginal Smears From the Beaver
}

\author{
Teresa DOBOSZYŃSKA
}

\begin{abstract}
Doboszczyńska T., 1976: A method for collecting and staining vaginal smears from the beaver. Acta theriol., 21, 22: 299-306 [With Plate X]

A description is given of a technique for efficient collection of vaginal secretions adapted to the anatomical structure of the terminal part of the genital system in the female beaver, and of a method for fixing and selective staining of vaginal smears.

[Inst. Fundament. Vet. Sci., Agric. Tech. Acad., 10-957 Olsztyn, Poland].
\end{abstract}

\section{INTRODUCTION}

In connection with the development of breeding beavers in captivity, dictated by the necessity for keeping extant species vanishing under of the animal's economically important values (valuable fur, castorenum and meat), a series of studies has been undertaken on the reproduction of these animals under conditions created by man.

In order to be able to intervene, through the medium of hormones, in the reproduction of the beaver, it would appear essential to examine the phases of the oestral cycle. It is well known that the vaginal epithelium is an excellent effector of ovarian hormones. Changes in the composition and structure of vaginal epithelium during different phases of the cycle are particularly distinct in small rodents such as the mouse, rat or nutria (Krupiński 1955; N a l bandov, 1966; Skowron- C e n drza k, 1956), and it may therefore be assumed that in the beaver, it should also prove possible to reveal changes taking place in the ovary by means of examination of vaginal smears.

Studies of the anatomical structure of the genital system in female beavers have shown that the true vagina of an adult animal (about $15 \mathrm{~cm}$ long and about $2 \mathrm{~cm}$ in diameter), ending in a short segment of the urogenital sinus, passes, together with the anus, by means of paired lateral recesses of the preputial fossa and paraproctial glands, into the pseudocloaca (Gi enc \& Doboszyńska, 1972; Doboszyńska, 
1974). It was simultaneously found that the wall of the pseudocluaca, the lateral recesses of the preputial fossa, the clitoris, preputial folds of the clitoris and the uregenital sinus, are covered with flat stratified epithelium, cornifying and exfoliating irrespective of the phases of the sexual cycle (Doboszynska, 1974). It is therefore essential to work out a technique permitting of collecting secretion directly from the true vagina.

The methods in general use for fixing and staining vaginal smears from different animals, such as those used by Passini (B u 1 l o u g h, 1949), Papanicolaou (1933, 1954), Krupiński (1955), have not given satisfactory results, and the lack of data in available literature dealing with this problem in the beaver induced the author to modify the fixing fluid and ascertain which composition of polychrome makes selective staining of smears possible, simultaneously taking into account variations in $\mathrm{pH}$ in its elements.

\section{METHOD}

The animals used the purpose were sexually mature, healthy females of the European beaver (Castor fiber L in n a e u s, 1758), obtained from the Popielno Experimental Station of the Polish Academy of Sciences*.

The contents of the beaver's vagina were obtained by means of simple instruments specially constructed for the purpose. The curettes were made from glass rods (25-30 cm long) appropriately shaped over a gas flame. The curette was housed in a slightly shorter tube $1-2 \mathrm{~cm}$ in diameter with smoothly ground edges. The curettes formed a set of varying sizes to allow for age and vaginal diameter of the females. The introduction of the curette into the vagina within a glass casing ensured that the secretion was taken from the true vagina and prevented collection of the contents of the lateral recesses of the preputial fossa or the pseudo-cloaca.

Before the secretion was collected the curette was immersed in physiological saline solution $(0.9 \% \mathrm{NaCl})$. After collection the secretion was placed on slides which had previously been cleaned to render them fat-free and damped with a drop of saline solution, then the smears were prepared. The slides were marked with diamonds shaped for this purpose in order to exclude any possible changes in $\mathrm{pH}$ due to introduction of pens for marking.

Papanicolaou's solution, consisting of $96 \%$ alcohol and ether (a : a) recommended by Krupinski (1955), was used for fixing for 15-30

* I must express my sincere gratitude to Dr. W. Żurowski of the Popielno Experimental Station of the Polish Academy of Sciences for placing the animal material at my disposal. 
minutes directly after preparing the smear. The fixed smear was dried for 30 minutes and whenever possible staining was begun immediately after this time. When preparations could not be stained directly after fixing they were placed for $2-3$ seconds in $0.2 \%$ colloidine $(1 \mathrm{~g}$ of colloidine in $100 \mathrm{ml}$ solution of ether and absolute alcohol after $\mathrm{Z}$ a w is tow sk i, 1970). This permitted to store slides for any desired time, and simultaneously prevented elements being washed away during further work on them.

In order to eliminate loss of elements in smears prepared for immediate staining after fixing, the bottom slides were covered in gelatine (B a g in s ki, 1969), and in such cases $0.2 \%$ celloidine was not used at all.

The polychrome used for staining the smears consisted of the following: (1) neutral red - an asine nucleus stain with amphoteric properties changing the stain depending on the environment $\mathrm{pH}$ (with $\mathrm{pH}-7.4-$ red, acid $\mathrm{pH}$ changes the stain to blue, basic to yellow), (2) ligth yellowish-green, (3) orange G, (4) yellowish eosine, (5) glycerol, (6) phenol, (7) phosphoromolybdenic acid.

\section{Method of preparing polychrome}

Solution A. Prepared by means of Twirt's method (B a g i ńs k i, 1969). 1.5\% solution of neutral red was mixed with an equal amount of $3 \%$ light yellowishgreen solution, dissolving the mixture at a temperature of $40-50^{\circ} \mathrm{C}$. The sediment left after decanting was dried at a temperature of $37^{\circ} \mathrm{C} .1 .3 \mathrm{~g}$ of the stain obtained was next dissolved in $100 \mathrm{ml}$ of methanol, adding in turn $10 \mathrm{ml}$ of $4 \%$ glycerol and $10 \mathrm{ml}$ of phenol, shaking thoroughly the whole time. The stain obtained in this way was a persistent mother liquor and when kept in a dark glass bottle could be used each time when preparing full polychrome.

Solution B. $2.5 \mathrm{~g}$ of orange $\mathrm{G}$ was dissolved in $50 \mathrm{ml}$ of distilled water at a temperature of $90^{\circ} \mathrm{C}$. $0.5 \mathrm{~g}$ of phosphoromolybdenic acid was added to the cooled solution to increase the affinity of the stain to cornified and corneous cells.

Solution C. 0.5 yellowish eosine was dissolved in $45 \mathrm{ml}$ of $96 \%$ alcohol at a temperature of $50^{\circ} \mathrm{C} 5 \mathrm{ml}$ of glycerol was added to the cooled solution, which was then well mixed.

Having the mother liquors ready, they were next filtered and then combined in the following parts: $25 \mathrm{ml}$ solution $\mathrm{A}+50 \mathrm{ml}$ solution $\mathrm{B}+50 \mathrm{ml}$ solution $\mathrm{C}$. The $125 \mathrm{ml}$ of polychrome obtained in this way, ready for use, was amply sufficient for staining approx, 60 smears.

\section{Smear staining technique}

1. The fixed preparations were passed in turn through the following alcohols: 96,80 and $50 \%$ to distilled water, leaving them for $3 \mathrm{~min}$. in each of them.

2. The preparations were next stained in the polychrome described for $20-35$ min, under microscope control.

3. Removal of excess stain and partial dehydration were carried out by passing the preparations through two successive glass vessels containing $96 \%$ alcohol.

4. Complete dehydrations was made in two successive absolute alcohols, after which the smears were irrediated in xylene and embedded in Canadian balsam. 


\section{RESULTS OF STAINING}

\section{Smears}

Cells originating from the deepest layers of the epithelium (Fig. 1-1 and Fig. 2-1), chiefly from the genital layer, were oval or scaphoid, wich average measurements of $15 \times 20 \mu \mathrm{m}^{* *}$. Their cytoplasm stained completely with yellowish green to an intensive green colour, while the nuclei stained with neutral red to a violet blue, with distinctly visible structures within the nucleus.

The cells of the middle layers of the epithelium, exhibiting certain characters of cornification (Fig. 1-2 and Fig. 2-3) were slightly larger cells, average size being $20 \times 30 \mu \mathrm{m}$. A cornified zone was observed round the nucleus in the cytoplasm of the majority of these cells, this zone staining with orange and eosine to an orange colour, with light green producing a light green limbus only peripherally. Their nuclei were pale blue with fine granules of chromatine.

The cornified cells of the epithelium, round or oval, $30 \times 50 \mu \mathrm{m}$ in size, were characterized by acidophilic cytoplasm staining orange, and vanishing, small, strongly basophilic, nuclei staining yellow. Nuclei of this type were similar to wringled peppercorns (Fig. 2-4).

The completely corneous cells, seen as large lobular formations $40 \%$ $60 \mu \mathrm{m}$ in size, had strongly acidophilic cytoplasm staining with orange and eosine to a reddish-orange colour. The nuclei disappear, leaving a trace, in the form of a lighter spot, in some of the cells only (Fig. 4).

In addition to the above elements numerous leucocytes, particularly segmented ones (Fig. $1-3$ and Fig. 2-5), with light green cytoplasm and acidophilic blue or dark blue nuclei, or only their naked nuclei in course of disintegration (Fig. 3-1), were found in the smears.

Numerous bands of mucus were observed in some of the smears (Fig. 1-4), and in others only its traces in the form of minute granular shadows between cells (Fig. 2-6). Mucus stains as follows depending on pH: blue-green to pink-yellow.

\section{Histological Sections}

The polychrome described above was also used for staining histological sections of the vagina (Fig. 5) for comparison with the pictures of smears.

The sections of the vagina used for this purpose were fixed in AFA fluid (B a g iński, 1969) and embedded in paraffin, using terpinol for transirradation. After sectioning and affixing on slides, the material

** The dimensions given for the cells were based on 500 measurements of each element. 
was cleaned of paraffin in the normal way. Further procedure was similar to that employed with vaginal smears, only the staining time being increased, depending on the thickness of the sections, from 30 to 50 minutes.

\section{DISCUSSION}

The technique for collecting vaginal secretions, fixing the smears and selective staining of components are all of great importance to a correct evaluation of histological pictures. As Krupins ki (1955), states, the method in general use for collecting secretions by means of an "eza" eyelet causes artificial detachment of the vaginal epithelium, resulting in obtaining, for instance, a picture of complete estrogenic irritation, anticipating the picture of the oestrus by many hours. In the cases of female beavers it was also impossible to use the glass rods employed by $\mathrm{Krupinski(1955)}$ on account of the possibility of collecting secretion from the region of the lateral recesses of the preputial fossa, that is, the so-called castoreum and consequently obtaining incorrect pictures. The small curette in its glass casing used by the author completely eliminates the possibility of this occurring.

Difficulties encountered during fixing of smears, connected primarily with elements being washed away during staining, were eliminated by embedding the slides in gelatine before preparing the smear, of covering the smear with a very thin layer of celloidine. Fixing smears while still wet in a mixture of $96 \%$ alcohol and ether and their direct staining (Krupiński, 1955), did not give the desired effects and simultaneously made it impossible to store the smears for any length of time without staining.

In order to differentiate the pictures trials were made with a large number of stains. Although staining with hematoxylin and eosine, Giemza's stain or methyl blue permitted of distinguishing the stage of corneous exfoliation from other periods in the cycle, differences in colour and morphological details of the cells were not sufficiently distinct. Passini's stain (B a lloug h, 1949) proved to be insufficiently "cytological" in the case of smears from the beaver, as had been the case in smears from mice, which Krupiński (1955) has accented. The cause of this was over-staining of the preparations (staining time 30 secs) which in effect produced blurred pictures. Pa pan ic ol a o u's polychromes (1933), used for human smears, but not giving correct differentiation in the mouse ( $\mathrm{Krupinski}$, 1955), was not only unattractive on account of the very long staining procedure, but also failed to give selective pictures in the case of the beaver. The best effects were obtained when the smears were stained with Krupinski's (1955) 
polychrome. The introduction of the modification described, however, consisting in using neutral red for staining nuclei, prepared after Twirt's solution (B a giński, 1960) instead of Romeis's hemalaun, permitted of discerning changes in the $\mathrm{pH}$ of the given elements of the smear and shortened procedure.

\section{CONCLUSIONS}

In accordance with the premises of exfoliative cytology the method presented complies with the following conditions:

1. Collecting vaginal contents from female beavers does not, as an operation, injure the animals.

2. The use of a curette in a glass casing permitted of collecting secretion from the region of the true vagina.

3. The material collected contains spontaneously exfoliated cells and not cells artificially detached from the group of tissues.

4. The prepared smears are fixed in such a way that they can be stored for a considerable time without staining.

5. Staining not only renders the morphological details distinct and permits of distinguishing cells, but also reflects the changes in $\mathrm{pH}$ in the nuclei of the cells and in the vaginal mucus.

6. The polychrome used is simultaneously suitable for staining histological sections in order to obtain comparisons with vaginal smears.

7. The method of collecting, fixing and staining material is suitable for mass application.

\section{REFERENCES}

1. Bagiński S., 1969: Technika mikroskopowa. Państw. Wyd. Nauk.: 1-729. Warszawa.

2. Bullough W. S., 1949: Passinis's stain for vaginal smears. J. Obst. Gynaec. British Empire, 56: $1-7$.

3. Doboszyńska T., 1974: Histomorfologia samiczego układu rozrodczego bobra europejskiego (Castor fiber Linna e us, 1758). Unpublished Ph. D. theses, Agric.-Techn. Acad., Olsztyn.

4. Gienc J. \& Doboszyńska T., 1972: Macromorphological description of the genital organs of the female beaver. Acta theriol., 17: 399-406.

5. Krupiński L., 1955: Nowa metoda barwienia rozmazów pochwowych. Folia biol., 3: 275-294.

6. Nalbandov A. V., 1966: Fizjologia rozrodu. Państw. Wyd. Nauk.: 1-289. Warszawa.

7. Papanicolaou G. N., 1933: The sexual cycle in the human female as reveled by vaginal smears. Amer. J. Anat., 52-519.

8. Papanicolaou G. N., 1954: Atlas of exfoliative cytology. Harvard University Press: $1-$. Cambridge.

9. Skowron-Cendrzak A., 1956: Dojrzewanie i rozród nutrii „Myocastor coypus" I. Cykl płciowy. Folia biol., 4: 119-138. 
10. Z a wistowski S., 1970: Technika histologiczna. Histologia oraz podstawy histopatologii. Państw. Zakł. Wyd. Lek.: 1-482. Warszawa.

Accepted, May 5, 1975.

Teresa DOBOSZYŃSKA

METODA POBIERANIA I BARWIENIA ROZMAZOW POCHWOWYCH U BOBRA

\section{Streszczenie}

Przystosowano metodę pobierania, ustalania i barwienia rozmazów pochwowych, mającą służyć w celu dokładnego poznania cytologii pochwy i faz cyklu rujowego u samic bobra europejskiego.

Do pobierania wydzieliny pochwowej posłużyły cienkie łyżeczki szklane umieszczone w szklanych osłonach. Utrwalone rozmazy w mieszaninie alkoholu $96 \%$ i eteru (a : a) wg Popanicolaou, ustalano przed suszeniem w $0,2 \%$ celloidynie. Tak utrwalone rozmazy mogły być barwione, bez szkody dla jakości otrzymywanych obrazów nawet po dłuższym okresie czasu.

Do barwienia rozmazów stosowano polichrom w oparciu o następujące składniki: czerwień obojętna, zieleń jasna, oranż G, eozyna, kwas fosforowo-molibdenowy, glicerol i fenol. 


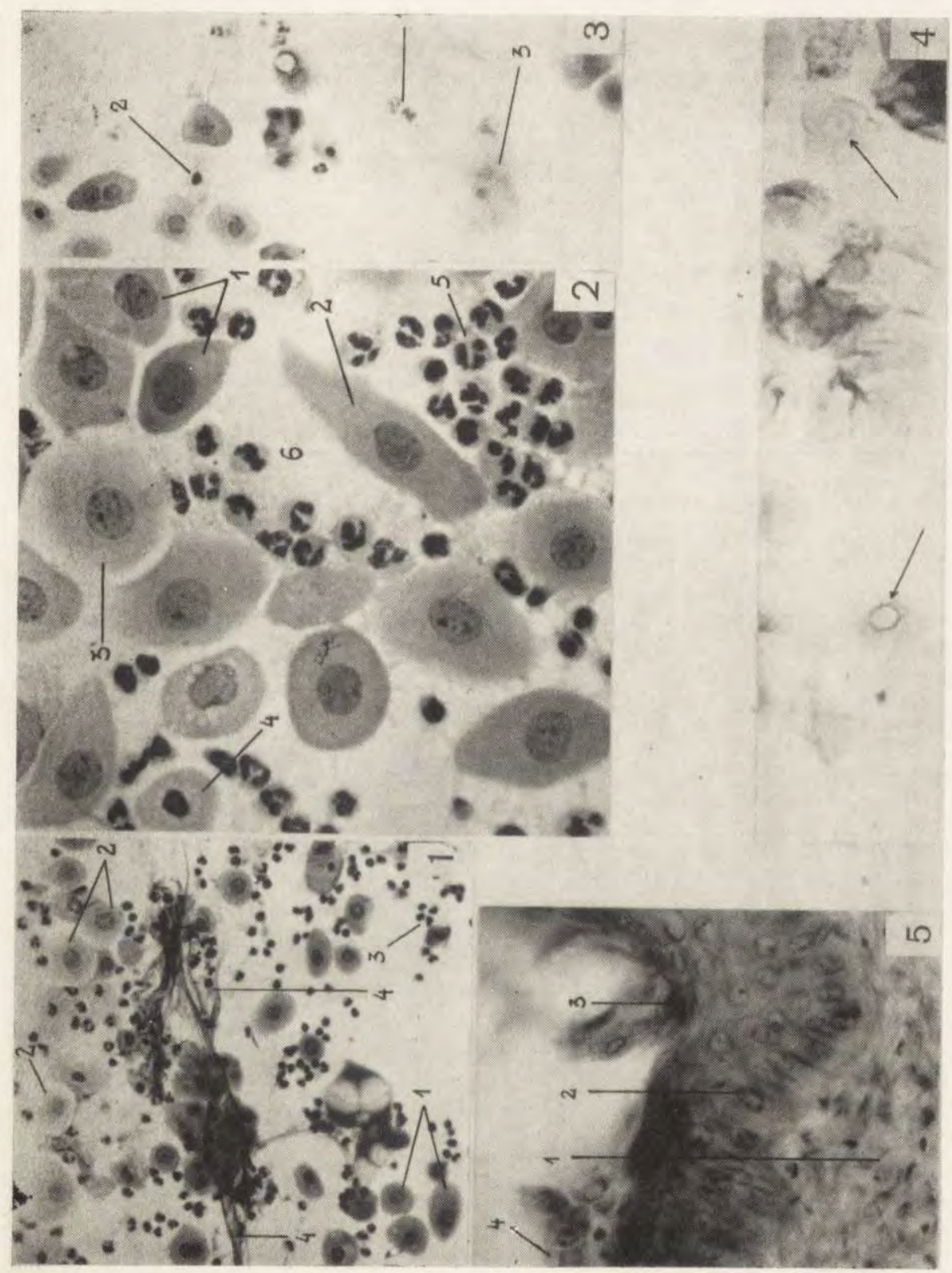

T. Doboszyñska

C. Nagięć phot. 
Fig. 1. General picture of a vaginal smear from a beaver. Magn. 250 $\times$.

1-groups of nucleated cells from the deeper layers of the epithelium, 2 cornifying cells, 3 -leukocytes, 4 - bands of mucus.

Fig. 2. Greatly magnified part of the same smear. Magn. $630 \times$.

1 - group of nucleated cells from the deeper layers of the epithelium, 2-glandular cells, 3-cornifying cell with visible cornifying zone round the nucleus, $4-$ cornifying cell with vanishing nucleus, 5-leukocytes, 6-fine, granulated mucus.

Fig. 3. General picture of a vaginal smear from a beaver. Magn. $250 \times$.

1 -disintegrating leukocytes, 2-cornifying cells with vanishing nuclei, 3 corneous cells.

Fig. 4. Corneous cells of epithelium, without nuclei (arrows indicate cells with visible traces of nuclei). Magn. $250 \times$.

Fig. 5. Histological picture of vaginal section. Magn. $250 \times$.

1 -mucous membrane, 2-basal layer of epithelium, 3-cornifying cells, 4exfoliated cells in the lumen of the vagina. 